\title{
Inflation Effects on Finance-Growth Link: A Panel Smooth Transition Approach
}

\author{
Mostafa Sargolzaei, Mohammad Mahdi Bahrololoum \\ Department of Finance and Banking, School of Management and Accounting, Allameh Tabataba'i University, Tehran, Iran \\ Email: mostafa.sargolzaei@atu.ac.ir,m.bah rololoum@gm ail.com
}

How to cite this paper: Sargolzaei, M. and Bahrololoum, M.M. (2019) Inflation Effects on Finance-Growth Link: A Panel Smooth Transition Approach. American Journal of Industrial and Business Management, 9, 1873-1879.

https://doi.org/10.4236/ajibm.2019.99120

Received: August 15, 2019

Accepted: September 16, 2019

Published: September 19, 2019

Copyright $\odot 2019$ by author(s) and Scientific Research Publishing Inc. This work is licensed under the Creative Commons Attribution International License (CC BY 4.0).

http://creativecommons.org/licenses/by/4.0/

\begin{abstract}
Considering the effect of inflation on financial development and economic growth, in this paper we investigate the role of inflation in the effect of financial development on the economic growth in OPEC economies for the period of 1970 to 2015. For this purpose, we used Panel Smooth Threshold Regression (PSTR) to estimate nonlinear effects of inflation in the relation between economic growth and financial development. The results of estimation show that the thresholds of inflation rate were 20.33 and 20.36 considering the two different proxies of financial development (domestic credit provided by banking and domestic credit to private sector). The results of nonlinear estimation showed that in over-threshold inflations, the effect of financial development on the economic growth in the OPEC economies would decrease and would even become negative.
\end{abstract}

\section{Keywords}

Credit Provided by Banking, Credit to Private, Economic Growth, PSTR, OPEC Economies

\section{Introduction}

Theoretically, the relation between development of financial sector and economic growth has been addressed for several years by most economists. Economists such as Bagehot (1873) [1], Schumpeter (1912) [2], Shaw and Gurley (1955) [3], Goldsmith (1969) [4] and Mckinnon (1973) [5] believe that in case the relation between financial sector and economic growth is ignored, the process of economic growth will not be understood completely.

There are many possible reasons why inflation might affect the finance-growth relationship. Intuitively, we know that when inflation rates are very high, the 
usefulness of money assets is eroded and there will be considerable uncertainty about future prices and interest rates. This uncertainty, in turn, may make financial intermediation-standing between lenders and borrowers-less efficient in allocating funds for investment, and may affect the ability of lenders to monitor projects. As a result, high inflation may weaken the link between finance and growth.

More precisely, inflation could alter the link between finance and growth in two key ways. First, inflation could affect the financial system's ability to accumulate capital - the amount of investment. In particular, when inflation is sufficiently high, the ability of financial intermediaries to raise capital may decrease, and thus the positive effect of financial development on capital accumulation may diminish. Second, inflation could affect the productivity of capital investment financed through the financial system. Intuitively, in high-inflation environments, even if the level of financing provided for capital investment is not affected, high inflation may decrease the productivity of accumulated capital, and this decrease will reduce the link between investment and economic growth.

In this paper, we examine the way in which the finance-growth relationship can vary according to the inflation rate. The non-linearity between finance and growth with respect to inflation might be connected to the fact that inflation negatively affects economic growth and thus results in financial repression.

\section{Theoretical Framework}

Mckinnon (1973) [5] and, Gurley and Shaw 1955 [3], showed the importance of an efficient financial system in the economic development in their works. They argued that the restrictions imposed by government on the financial sector (such as control of interest rate, high rate of reserve with central Bank, allocation of bank credits, etc.) could cause some problems in the development of financial sector and as a result restriction of real sector.

While intensive studies have examined the relationship between finance and growth, very few efforts have been made to identify why a link exists between finance and growth. Empirical studies on the issue of whether the finance-growth relationship is due to the "capital accumulation channel" or the "productivity channel" are mixed and surprisingly Scarce (Li Min, 2006) [6].

The previous studies have generally assumed a constant relationship between finance and growth. That is, they have not considered whether economic conditions, such as the rate of inflation, are associated with a stronger or weaker finance-growth relationship (Li Min, 2006) [6].

Only a few studies appraise the relationship between inflation, financial development and growth.

Haslag and Koo (1999) [7] and Boyd et al. (2001) [8] show that inflation is associated with financial repression. Andres et al. (1999) [9] pointed out that empirical studies have focused on either the finance-growth relationship or the inflation-growth relationship, but not linked the two. Rousseau and Wachtel 
(2002) [10] identify an inflation threshold for the finance-growth relationship, finding that finance affects growth positively only when annual inflation can be held below a threshold that lies between 13 and 25 percent, depending on the measure of financial depth that is chosen. They also find that disinflations are related to strong positive effects of finance on growth. More recently, Rousseau and Yilmazkuday (2009) [11] have extended the work of Rousseau and Wachtel (2002) [10] through a trilateral graphic approach and threshold analysis. They find that small increases in the price level seem able to wipe out relatively large effects of financial deepening when the inflation rate lies between $4 \%$ and $19 \%$, whereas the finance-growth relationship is less affected by inflation rates above this range.

\section{Research Methodology}

To allow for nonlinearities we use a transition regression model based on panel data (PSTR).

Smooth transition regression model is a non-linear time series model that can be considered as a more developed species of regression models with varying coefficients that has been introduced by Bacon and Wats (1971) [12]. For first time in time series literature, Grenger-Trasorta (1993) [13] has described and suggested STR smooth transition model in their studies. PSTR model may be specified into either exponential smooth transition model (ESTR) or logistic smooth transition (LSTR) as following:

$$
g_{i t}=\alpha_{i}+\beta_{0} F_{i t}+\beta_{1} F_{i t} G\left(q_{i t}\right)+\delta Z_{i t}+U_{i t}
$$

LSTR: $G\left(q_{i t}\right)=1 /\left(1+\exp \left\{-\gamma\left(q_{i t}-c\right)\right\}\right)$

ESTR: $G\left(q_{i t}\right)=1-1 /\left(1+\exp \left\{-\gamma\left(q_{i t}-c\right)^{2}\right\}\right)$

where $g_{i t}$ is the GDP growth rate observed for the $i$ th country at time $t . \alpha$ is intercept, $F_{i t}$ is the financial development indicator (we used the domestic credit provided by banking sector (\% of GDP) and the domestic credit to private sector (\% of GDP) as the proxies of financial development), and $Z_{t}$ is vector of control variables (used control variables such as Population growth, Government size, and sum of exports and imports as a share of GDP to capture the degree of openness of an economy). In this specification, the coefficients of explanatory variables are not constant and are functions of $q_{t}\left(q_{t}=\right.$ the inflation rate), namely, transition or threshold variable. $G\left(q_{t}\right)$ is transition function, c is threshold parameter and $\gamma>0$ is smooth parameter. The transition function is between zero and one. This function is mainly dependent on transition variable $\left(q_{t}\right)$, threshold parameter $(c)$ and the smooth parameter $(\gamma)$.

The above specification indicates that model can be interpreted as a linear model with stochastic time-varying coefficients. For LSTR model, coefficients of $\beta_{0}+\beta_{1} G\left(q_{t}\right)$ change monotonically as function of $q$ from $\varphi$ to $\beta_{0}+\beta_{1}$ (when $q_{t}$ moves from $-\infty$ to $+\infty$ ). But at ESTR function, coefficients change symmetrical about middle point $\mathrm{c}$ from $\beta_{0}$ to $\beta_{0}+\beta_{1}$ (when $q_{t}$ moves from 
$c$ toward $\pm \infty)$. Thus LSTR model is able to model symmetrical behavior of variables. For example, this model is proper where boom periods show different behaviors from depression ones and transition from one regime to another regime takes place smoothly. On the other hand, the ESTR model is appropriate in situations in which the local dynamic behavior of the process is similar at both large and small values of $q_{t}$ and different in the middle. When smooth parameter is $\gamma=0$, the transition function will be $G\left(q_{t}\right)=1$ and thus STR model will change into a linear model. On the other hand, when $\gamma \rightarrow \infty$, the LSTR model will change into regression model with 2 discrete regimes. At ESTR model, if $\gamma \longrightarrow \infty$ in fact it leads to a linear model.

\section{Estimation and Specification Tests}

The data includes a panel of 14OPEC economies during the years 1970-2010. The data are obtained from WDI (2011) database.

Before estimating PSTR model, we first should test the linearity hypotheses. If an $H_{0}$ hypothesis is rejected, we are estimating the model by method of Non-linear least squares (Table 1). The linearity hypotheses can be specified as follows:

$$
H_{0}: \gamma=0 \text { or } \beta_{1}=0
$$

In fact, in both cases the test statistics does not have standard distribution, so that with $H_{0}$ hypothesis, the PSTR model statistics will include nuisance parameters. To tackle the mentioned problem, we can be done using Lagrange multiplier statistics (LM) as the following: considering SSR0 as the square of panel error in $H_{0}$ hypothesis (panel model with individual effects) and SSR1 as sum of squares of panel error in $H_{1}$ hypothesis or PSTR, the LM statistics will be equal to the following:

$$
L M=\left(S S R_{0}-S S R_{1} / K\right) /\left(S S R_{0} /(T N-N-K)\right)
$$

where $T$ is the number of years, $N$ the number of countries, and $K$ the number of explanatory variables.

According to the null hypothesis, the statistics of Lagrange multiplier will be of chi-square distribution with the degree of freedom $\mathrm{K}$ and the corresponding $F$ statistic will be of the distribution $F(K, T N-N-K)$.

\section{Estimate of PSTR Model}

After confirming the existence of non-linear relationship between economic growth and inflation on financial development, we estimate on-linear regressions by PSTR model. The results of the approximation are indicated in Table 2.

The results of the approximation of PSTR model indicate that threshold parameter of inflation is equal to 20.33 and 20.36 in the relationship between economic growth and financial development. In view of the approximation of the parameter of $\beta_{0} \& \beta_{1}$ we can say that in the low-rate inflation regime the effects of the financial development on the economic growth are constructive and positive. But in the high-rate inflation regime the effects of the financial 
Table 1. LM tests for remaining non-linearity.

\begin{tabular}{ccc}
\hline Model & Model A & Model B \\
\hline Financial variable & Credit provided by banking & Credit to private \\
Threshold variable & Inflation & Inflation \\
Fstatistic & $13.23[0.00]$ & $14.76[0.00]$ \\
\hline
\end{tabular}

Note: The corresponding $p$-values are reported in brackets.

Table 2. Parameter estimates for the PSTR model.

\begin{tabular}{ccc}
\hline Model & Model A & Model B \\
Financial variable & Credit provided by banking & Credit to private \\
\hline Intercept $\beta_{0}$ & $6.07[0.08]$ & $9.57[0.00]$ \\
Parameter $\beta_{1}$ & $0.02[0.17]$ & $-0.005[0.76]$ \\
Parameter & $-0.08[0.02]$ & $-0.12[0.01]$ \\
Threshold Parameter (c) & 20.33 & 20.36 \\
Smooth Parameter $(\gamma)$ & 6 & 6 \\
\hline & Control Variables & $0.001[0.96]$ \\
\hline Openness to trade & $0.03[0.4]$ & $0.9[0.00]$ \\
Population growth & $0.57[0.05]$ & $-0.04[0.08]$ \\
Inflation rate & $-0.02[0.52]$ & $-0.45[0.00]$ \\
Government size & $-0.37[0.00]$ & 0.27 \\
\hline R-Squared: & Diagnostic Test Statistics & 1.55 \\
DW & 0.13 & $15,134.91$ \\
SSR & 1.43 & 0.000 \\
\hline Prob (F-statistic) & $15,439.08$ & \\
\hline
\end{tabular}

Note: The brackets indicate significance level of estimated coefficients ( $p$-values).

development on the economic growth are negative. As a result we can say that in the OPEC the effectiveness of the financial development on the economic growth is dependent on the economic conditions and lying in the high-rate or low-rate inflation.

Considering the results of Table 2, it can also be said that openness to trade and population growth in the OPEC economies will have positive and significant effects on the economic growth, but inflation rate and government size will have negative effects on the economic growth.

\section{Conclusion}

In this paper, we investigated the effect of inflation in the relation between financial development and economic growth in OPEC economies for the period of 1970 to 2015. We used Panel Smooth Threshold Nonlinear Regression for this purpose. For financial development, we used two proxies, namely domestic cre- 
dit provided by banking and domestic credit to private sector and we estimated two separate regressions. The results showed that there was no significant difference in the selection between the two proxies of financial development in the results of estimation. The results showed that the inflation threshold rate would be 20.33 and/or 20.36. The results further showed that the effect of financial development on the economic growth will decrease in over threshold rates and even the effect of financial development on the economic growth in high inflation rates will be negative.

\section{Conflicts of Interest}

The authors declare no conflicts of interest regarding the publication of this paper.

\section{References}

[1] Bagehot, W. (1873) Lombard Street. Richard D. Irwin, Homewood. (1962 Edition)

[2] Schumpeter, J.A. (1912) The Theory of Economic Development. Dunker \& Humblot, Leipzig. Translated by Opie, R., Harvard University Press, Cambridge, 1934.

[3] Gurley, J.G. and Shaw, E.S. (1955) Financial Aspects of Economic Development. American Economic Review, 45, 515-538. http://www.jstor.org/stable/1811632

[4] Goldsmith, R.W. (1969) Financial Structure and Development. Yale University Press, New Haven. http://www.jstor.org/stable/2230134

[5] McKinnon, R.I. (1973) Money and Capital in Economic Development. Brookings Institution, Washington DC.

[6] Li, M. (2006) Inflation and Economic Growth: Threshold Effects and Transmission Mechanisms. Department of Economics, University of Alberta, Edmonton, 8-14.

[7] Haslag, J. and Koo, J. (1999) Financial Repression, Financial Development and Economic Growth. Federal Reserve Bank of Dallas Working Paper 99-02. http://dallasfed.org/research/papers/1999/wp9902.pdf

[8] Boyd, J., Levine, R. and Smith, B. (2001) The Impact of Inflation on Financial Sector Performance. Journal of Monetary Economics, 47, 221-248.

https://doi.org/10.1016/S0304-3932(01)00049-6

http://www.econ.brown.edu

[9] Andres, J., Hernando, I. and Lopez-Salido, J.D. (1999) The Role of the Financial System in the Growth-Inflation Link: The OECD Experience. Banco de Espana Working Paper, 99-20.

http://www.bde.es/webbde/SES/Secciones/Publicaciones/PublicacionesSeriadas/Doc umentosTrabajo/99/Fic/dt9920e.pdf

[10] Rousseau, P.L. and Wachtel, P. (2002) Inflation Thresholds and the Finance-Growth Nexus. https://ssrn.com/abstract=315967 https://doi.org/10.2139/ssrn.315967

[11] Rousseau, P. and Yilmazkuday, H. (2009) Inflation, Financial Development, and Growth: A Trilateral Analysis. Economic Systems, 33, 310-324. https://doi.org/10.1016/j.ecosys.2009.06.002

[12] Bacon, D.W. and Watts, D.G. (1971) Estimating the Transition between Two Intersecting Straight Lines. Biometrika, 58, 525-534.

http://www.jstor.org/stable/2334387 
https://doi.org/10.2307/2334387

[13] Granger, C.W.J. and Terasvirta, T. (1993) Modeling Nonlinear Economic Relationships. Oxford University Press, New York.

https://doi.org/10.1093/acprof:oso/9780199587148.001.0001 